\title{
Exploration on the Construction of Educational Law Discipline and Talent Cultivation
}

\author{
Jie He \\ Kunming University, School of Social Management, Kunming, Yunnan, 650214
}

Keywords: construction; educational law discipline; talent cultivation

\begin{abstract}
At this stage, China's open educational law discipline has gradually begun to show a downward trend in the cultivation of talents. Due to the gradual increase in the requirements of law-related work for service personnel, the popularity of open educational law discipline among students has gradually declined. Therefore, from the perspective of employment at the current stage, colleges and universities have updated the training model for open educational law discipline, so as to further develop open educational law discipline and promote the development of open educational law in China.
\end{abstract}

\section{Introduction}

Building a socialist country under the rule of law is one of the basic goals of our country's social development. Legal education plays an indispensable and important role in achieving this goal. It bears the dual task of inheriting knowledge and cultivating talents. It is a long way to go. Because, the inheritance and innovation of knowledge and highly specialized and qualified legal talents are the two pillars of the rule of law. However, in fact, under the premise that China's legal education bears the historic mission of building a socialist country under the rule of law, not only has legislation, judiciary, legal services, legal supervision, and other legal departments been trained to be adequate, specialized, and of high quality. The legal talent also contributes to the development of a variety of high-level, high-quality learning methods and law-abiding talents needed to build a socialist country under the rule of law. More importantly, it also failed to make effective use of the spread of legal culture to the entire society, creating a good environment for the rule of law, shaping the legal professional community, and cultivating high-level legal researchers. The fact that China's legal education has faltered in the process of "false prosperity" 1 can not help but embarrass people. Therefore, it is necessary to explore the scientific development of Chinese legal education in such a context.

\section{Practical Conditions for the Construction of Educational Law Discipline}

The emergence of any discipline is based on the professional needs of the community. This occupational counterpart in disciplinary construction is called the professional orientation of subject talents in pedagogy. Conversely, professional orientation refers to the social profession and related professional groups that a subject's talent design should bear. Educational law subjects must master the relevant knowledge, professional ethics, and professional skills of pedagogy and law, so the cultivated talents are also more professional. The first is teachers and researchers engaged in legal education at all levels and in all kinds of educational activities, followed by administrative personnel, education and teaching managers who implement education management and law education according to law, and once again the legal education propaganda workers of the judicial department. People will also be judges in juvenile courts. The comprehensive management of the country according to law has been identified as one of China's four strategic layouts. From the perspective of the construction of a "rule of law state," education is a cultural highland of the country and should play a leading and exemplary role in implementing the strategy of governing the country according to law. Part VI of the "Decision of the Central Committee of the Communist Party on Resolving Several Major Issues Concerning the Comprehensive Ruling of the Country by 
Law" clarifies the need to "strengthen the construction of the work force of the rule of law," and this section "(3) Innovates the mechanism for the cultivation of the rule of law talents. Insisting on Marxist legal ideas and Chinese characteristics The socialist theory of theories of the rule of law occupies a full range of legal education and law research positions in universities and scientific research institutions, strengthens research on the basic theories of law, forms a perfect socialist legal theory system, disciplinary system, and curriculum system with Chinese characteristics, and organizes the preparation and adoption of national unified laws. The core professional teaching materials of the professional category are included in the scope of the compulsory examination for judicial examinations, which further clarifies the importance and specific practices of the state in promoting the cultivation of the rule of law talents. Whether it is economic, political or cultural construction or social management, it requires a lot of support from the rule of law talents. The foundation of the entire social building also requires a significant increase in the learning of citizens' legal knowledge and awareness of the rule of law. It is this social demand that provides a solid career foundation for the cultivation of educational law talents and the construction of educational law disciplines.

\section{Problems Existing in the Construction of Educational Law Discipline}

Education law is a new discipline that intersects law and education, and cross-cutting is not only the advantage of its emergence and development, but also the cause of its development. Educational law as a course has been recognized in the pedagogy and legal talent training system; the establishment of educational law as a secondary discipline or orientation under the pedagogic or law discipline has started the education law curriculum group. Construction; Educational law courses have also been set up in colleges and universities for teacher qualification training, primary and secondary school teacher qualification exams, and various types of educational administrative training. Because the educational law curriculum not only contains the basic knowledge of legal theory (such as jurisprudence, general principles of civil law, general principles of criminal law, constitutional law, administrative law, procedural law, etc.), it also includes specific understanding and application of laws, regulations, and rules of educational law. . Within the limited number of years of study and class hours, whether it is for the study of graduate students or undergraduates, or the training of primary and secondary school teachers, if the subjects of the study are to grasp the content of the educational law curriculum, even if it is the most basic, that is, only those who must be familiar with The concept of law enables it to communicate with law researchers or judicial practitioners in a barrier-free manner. Even if 60 hours or more is given, it is almost impossible to accomplish. Judging from the author's experience, even students who have studied jurisprudence have little knowledge of learning the curriculum of educational law and need teachers to supplement many legal and political sciences. At the same time, if the teacher does not have a knowledge background in jurisprudence, constitutional law, civil law, criminal law, administrative law, and procedural law, he or she will not be able to complete the teaching of educational law, which is also the fundamental reason for the impediment of the development of education law disciplines in the education field. Therefore, strengthening the share of legal knowledge in educational law disciplines is an urgent issue to be solved in the discipline of educational law under the pedagogic discipline.

Under the discipline of law, education law courses are mainly established by the Constitution and Administrative Law Teaching and Research Section, and are only optional courses in law undergraduate and postgraduate education. Law schools of comprehensive universities do not have any education law courses, even if there are independent law schools. Recognizing the status of educational jurisprudence, it is only under the "constitutional and administrative jurisprudence" that sets the direction of education law parallel to the constitution and administrative law. Because there are still many problems to be solved by law itself, and there is still a long way between the law and the reality of the rule of law in China, the jurists themselves continue to utter the tragic voice of “Where does Chinese jurisprudence go?”[15]. Education law is not affected by the discipline of law. The emphasis is also reasonable. 


\section{Talent Cultivation in Educational Law Discipline}

Although education law is a discipline that intersects pedagogy and law disciplines, as the number of educational law research teams in the education community is now larger, the academic leaders are more enthusiasm, the second-level disciplines are actively being set up, and personnel training is also established. Educational Administration and School Managers' Occupational Orientation. However, most of the educational law researchers who have grown up from pedagogy do not have the background of legal education, and they do not have access to judicial practice. The courses offered in the training of talents are more education courses such as education policy and education management. There are few special courses in law, and there are fewer legal practice observations and internships in judicial practice departments. The ingredients of "law" in personnel training are insufficient. If this continues for a long time, it will inevitably affect the development of educational law disciplines. Therefore, the construction of educational law disciplines in pedagogy must strengthen the "law" factors. The main ones are the promotion of teaching materials for educational law, the establishment of "Introduction to educational law" in undergraduate majors in education, and the orientation of courses aimed at cultivating students according to law. The concept of administration and education in accordance with the law and students' understanding of the education laws and understanding of the normative documents of the skills training. The jurisprudence, constitutional law, general civil law, general criminal law, administrative law, and procedural law are the basic professional courses for graduates of education law degree graduates, and the cultivation of students' legal thinking skills can only enable the talents we cultivate to have not only laws. People grasp the "ethical bottom line" and "clearly distinguish the subject's rights and obligations" of the way of thinking, while not forgetting the particularity of the phenomenon of education, have the educational "perfect" feelings of thinking, can better deal with educational legal issues, coordinate well The relationship between compulsory and violent laws and the public welfare of education, goodness, development, and infinite possibilities can better resolve educational disputes.

As a very important indicator of educational law disciplines serving the society, educational law disciplines have therefore received widespread social acceptance. The educational law discipline should pay more attention to the content of "law and law knowledge" prescribed in the Interim Measures for the Qualification Examination for Primary and Secondary School Teachers, and should earnestly study the knowledge of education laws and regulations and the concept of the rule of law that are required for various types of teacher occupations. In the spirit of law, we have compiled reference materials for "legal and legal knowledge" that are required for various types of teacher qualification examinations, to increase the awareness of the rule of law and to understand education laws and regulations of teachers' professional staff, and to expand the influence of educational law disciplines.

With the improvement of the education level in our country, the entry threshold for teachers' professional and judicial careers has also been continuously improved. Although there are no changes in the academic qualifications of the state for all types of teachers and judges, prosecutors, and lawyers at all levels, it is not surprising that graduates with Ph.D. degrees go to middle schools or even elementary schools to become teachers. The entry into the judiciary has become quite difficult. At present, the number of undergraduate enrollment in pedagogic majors at the top national teachers' colleges has dropped sharply. Instead, postgraduates majoring in education master degree programs based on other disciplines have been recruited. Although the size of undergraduate students in law is very large, the employment rate of law undergraduates has always been at the end of each major, and this has been widely criticized by society. This kind of educational phenomenon precisely confirms a common feature of undergraduate education in pedagogy and law. Education that aims at professional needs tends to follow the path of postgraduate education for majors, that is, to study law or pedagogy on the basis of the first undergraduate major. . Therefore, the country can set up a master's degree in education law, training senior professionals in education law. It not only meets the needs of talents for education management and legal administration, but also lays a solid foundation for education law education. 


\section{Conclusion}

To realize the cultivation of open education law professionals, it plays an important role in the reform and optimization of teaching models and teaching resources. The article further studied the creation of the four-step process of improving investment in the open education law professional education team, optimizing the teaching process of open education law, establishing an open education law teaching system based on the Internet, and optimizing the teaching resources of open education law. To cultivate the mode of cultivation of open education jurisprudence personnel, thus realizing the training of professional talents and promoting the development of our country's open education law major.

\section{References}

[1] Jiang Chao. A Study of Some Issues Concerning the Construction of China's Educational Law Discipline [J]. Kangding Journal, 1997(4).

[2] Yan Hongqi. The Turning and Reconstruction of Educational Law [J]. Journal of Beijing Normal University: Social Science Edition, 2013(5).

[3] Tan Xiaoyu. Thinking on Chinese Educational Law Research and Development Problems in China [J]. Forum on Contemporary Education, 2003(6).

[4] Yu Yafeng, Lao Kaisheng. Retrospect and Prospect of 30 Years of China's Educational Law Research in Reform and Opening-up [J]. Educational Research, 2009(2).

[5] Qin Huimin. The background and research status of the development of Chinese educational jurisprudence $[\mathrm{M}]$. Lou Kaisheng. Chinese Education Legal Review: No.6. Educational Science Press, 2009. 